\title{
THE CONIFEROUS ANTHROPOGENIC AND NATURAL FORESTS DECLINE IN SERBIA DRIVEN BY DIFFERENT ABIOTIC AND BIOTIC FACTORS
}

\author{
Mara TABAKOVIĆ-TOŠIĆ ${ }^{1}$, Ivan MILENKOVIĆ ${ }^{2}$, Zlatan RADULOVIĆ
}

\begin{abstract}
The epidemic dieback of conifer forest, as the modern phenomenon, is present in the central part of the Republic of Serbia as well as in other countries of Southeastern Europe. Affected forest area increased in the period 2011-2014. It was most intense in forest stands dominated by spruce and silver fir, and about eight-fold less intense in Austrian and Scots pine. Change in climate conditions is supposed to be one of the main possible causes of coniferous forests dieback.

The climate change initiated the increased activity of fungi Armillaria spp. and Heterobasidion annosum which led to the decay of individual trees and spreading in groups of trees. In pine and spruce monocultures afforested within the broadleaved habitats, massive dieback of trees was also a consequence of these two fungi.

Spatial and temporal scales of insect outbreaks increase due to dry summers and mild winters in high elevations. In the last decade, in the coniferous plantation and natural forests in the central part of Serbia, intense outbreaks of bark beetles on spruce and silver fir were recorded. Spruce forests were heavily attacked by Ips typographus and Pityogenes chalcographus, and Austrian and Scots pine forests have been mostly affected by forest fires followed by outbreaks of Ips sexdentatus and other bark beetles. Insufficient silvicultural measures and inappropriate forest management in silver fir forests contribute to mistletoe infestations.
\end{abstract} factors

Key words: coniferous, anthropogenic and natural forests, decline, harmful

\footnotetext{
${ }^{1}$ Mara Tabaković-Tošić PhD, Principal Research Fellow, Institute of Forestry, Belgrade

${ }^{2}$ Ivan Milenković, PhD, Research Associate, Institute of Forestry, Belgrade

${ }^{3}$ Zlatan Radulović, PhD, Research Associate, Institute of Forestry, Belgrade

Translation: Mara Tabaković-Tošić
} 


\section{PROPADANJE ČETINARSKIH ANTROPOGENIH I PRIRODNIH ŠUMA U SRBIJI, UZROKOVANO RAZLIČITIM BIOTIČKIM I ABIOTIČKIM FAKTORIMA}

Izvod: Epidemijsko sušenje četinarskih šuma, kao savremeni fenomen, kao i u drugim zemljama jugoistočne Evrope, prisutno je i centralnom delu Republike Srbije, gde je u periodu od 2011. do 2014. godine došlo do značajnijeG povećanja ugroženog šumskog područja. Najizraženije je u šumskim sastojinama gde dominira smrča i jela, dok je oko osam puta slabijeg intenziteta $u$ antropogenim i prirodnim šumama belog $i$ crnog bora. Promenjeni klimatski uslovi su jedan od glavnih mogućih uzročnika sušenja prethodno navedenih vrsta drveća.

Klimatske promene inicirale su pojačanu aktivnost gljiva Armillaria spp. $i$ Heterobasidion annosum, a one su dovele do propadanja pojedinačnih i grupa stabala. Sušenje stabala smrče $i$ borova u monokulturama podignutim na lišćarskim staništima, takođe je uzrokovano navedenim vrstama gljiva.

Pojave prenamnoženja gradogenih vrsta insekata, te širenje površina pod napadom, intenzivirane su sušnim letima i blagim zimama na višim nadmorskim visinama. U području centralne Srbije, poslednje decenije, u četinarskim antropogenim i prirodnim sastojinama smrče i jele, došlo je do gradacije potkornjaka. Smrčeve šume su napadnute od strane dve najznačajnije ekonoski štetne vrste Ips typographus i Pityogenes chalcographus, a sastojinama crnog I belog bora, pogođenim šumskim požarima i ledolomima, preti opasnost od, za njih najznačajnije vrste potkornjaka, Ips sexdentatus, kao $i$ drugih ksilofagih insekata. Kada je u pitanju jela, u pojedinim područjima centralne Srbije, usled nedovoljnih uzgojnih mera i nepravilnog gazdovanja, najviše je ugrožena poluparazitnom cvetnicom - imelom.

Ključne reči: četinari, antropogene i prirodne šume, sušenje, štetni faktori

\section{INTRODUCTION}

Forests, by their structure, as well as by connections and relations among some members, belong to the category of the most complex ecosystems on the Planet. The stability of the forest ecosystems to a great extent depends on the impact, i.e. presence of the different harmful abiotic and biotic factors at the global and local levels. At the local level, it refers to the plant diseases, economically harmful living organisms, climate factors, local environment pollution, whereas at the global level it refers to the climate change, reflected in the global warming which is the result of the ozone layer depletion.

The climate is regarded as the main ecological abiotic factor and it is inextricably bound to some ecosystems, i.e. their presence depends upon climate, and, therefore, it is of special importance to their development and stability. The climate parameters influence the soil fertility, vitality of plants, aggressiveness and pathogenicity of fungi which inhabit certain tissues of host plant, and population dynamics of so-called "useful and harmful" forest insects.

About $90 \%$ of all natural disasters, which occurred since 1980 have been directly or indirectly attributed to the weather and climate. About $95 \%$ of the economic losses caused by the catastrophical events are the result of the climaterelated disasters. The annual number of the disasters caused by the weather and 
climate in Europe increased by about $65 \%$ over the period 1998-2007 in the comparison with the annual average value for 1980. It is estimated that in the next decades the losses caused by the natural disasters will be dominant, and that in the second half of the next century the effects of the climate change on the economy will be more expressed (Rosenzweig et al., 2001).

Forest productivity and species diversity typically increase with increasing temperature, precipitation and nutrient availability, although species may differ in terms of their tolerance (Das, 2004). The impacts of elevated temperatures on trees and plants will vary throughout the year since warming may relieve plant stress during colder periods but increase it during hotter periods (Garrett et al., 2006). Moisture availability in forests will be strongly influenced by changes in both temperature and precipitation. Warmer temperatures lead to increased water losses from evaporation and evapotranspiration and can also result in reduced water use efficiency of plants (Mortsch, 2006). Longer, warmer growing seasons can intensify these effects resulting in severe moisture stress and drought. Moisture stress and drought can also impact forest health by enhancing susceptibility to disturbances such as insect pests and pathogens and forest fires.

The impact of the climate change on the ecosystems, which mainly refers to the warming caused by the anthropogenic increase of the glass house gases $(\mathrm{C}$, $\mathrm{CH} 4, \mathrm{~N} 2 \mathrm{O}, \mathrm{O} 3, \mathrm{HCFCs}, \mathrm{CFCs}$ ), which will initiate the numerous adverse effects on the forest ecosystems, has been elaborated in the domestic and foreign literature. For instance, Willmott and Legates (1991) report that the increase of temperature ensured the sufficient energy for the increased transpiration and evaporation, and owning to the limited capacity of the atmosphere to absorb the moisture, all these phenomena have been globally reflected in the increase of the precipitation (Quoted by Liovic and Zupanic, 2005). The increased precipitation are not uniformly distributed, so in some regions the floods and soil erosion can be expected, whereas the decrease in precipitation and accelerated forest desiccation (Bradley et al., 1987).

\section{RESULTATES AND DISCUSION}

Each species has well-defined ecological amplitude, which can be either narrow or broad, depending on the effects of certain abiotic and biotic factors. If the values of certain parameters are outside the limits, they directly affect the survival of the species in a given area, i.e. they become a limiting factor. In the forests area in Southeastern Europe change in climate conditions is on the first places of the possible causes of desiccation.

Change in climate conditions is supposed to be one of the main possible causes of coniferous forests dieback in forest area of Southeastern Europe. At the global level, the year of 2013 was together with the year of 2003 the fourth hottest year since the beginning of measurements in 1880 . The average global temperature was by $0.62^{\circ} \mathrm{C}$ above the average $\left(13.9^{\circ} \mathrm{C}\right)$ for the period $1981-2010$. The hottest year was 2010, and nine out of ten hottest years in a 134 year-long measurement series occurred in the period from 2000 to today. Furthermore, the year of 2013 was the thirty-seventh consecutive year with the temperatures above the average. 
These data indicate a significant change in climate and a steady increase in global temperature.

A severe ice storm accompanied by heavy rainfall hit the area of central Serbia (State Enterprise Srbijašume: Forest Estates Niš, Timočke šume Boljevac, Južni Kučaj Despotovac, Rasina Kruševac, Severni Kučaj Kučevo; 18,500 ha of state forests) in late November and early December 2014 and caused unprecedented ice breakages in artificially-established conifer stands, mostly of spruce and Austrian pine. The most vulnerable area was the Forest Estate Timočke šume Boljevac with 10,060.72 hectares (Srbijašume estimate: 979,682 $\mathrm{m}^{3}$ of damaged or dead trees) (Tabaković-Tošić \& Milosavljević, 2015).

The population density of the four of bark beetle species [Ips typographus (Linnaeus, 1758), I. acuminatus (Gyllenhaal, 1827), Ips sexdentatus (Börner, 1767) and Pityogenes chalcographus (Linnaeus, 1761)] in artificially-established conifer stands damaged by ice-breaks in 2014, in the area of Central Serbia was managed using traps with specific pheromone dispensers - synthetically produced aggregation pheromones. The obtained results, with the above-stated exceptions, generally do not indicate an increase in their abundance. However, in the future, weather conditions favourable for their development (mild winters) in the absence of urgent control measures may turn these species into a calamity of bigger proportions (Tabaković-Tošić \& Milosavljević, 2015).

The epidemic dieback of conifer forest, as the modern phenomenon, is present in the most countries of Southeastern Europe. Affected forest area increased in the period 2011-2014. For example, the massive desiccation of individual or groups of trees in 2013 was reported in all areas of Serbia. It was most intense in the spruce and fir, and about eight-fold less intense in the Austrian and Scots pines. The intensity of desiccation is expressed by the timber volume marked for the sanitation felling and in the case of spruce and fir it is $103,239 \mathrm{~m}^{3}$, and in the case of pines it is 13,051 $\mathrm{m}^{3}$ (Tabaković-Tošić, 2014).

Mediterranean pluviometric precipitation regime, which is unfavourable to the forest due to the spring and autumn maximum, is ideal for the development of the parasite fungi. Therefore, there are great possibilities for the occurrence of the fungal diseases, which will be multiplied every year.In the regions with moderate climate the most frequent plant pathogens decrease their activity during the winter and in the early spring due to the low temperatures. Although there are some diseases which have been favoured over the cold period, many species favour the higher temperatures. The increase of temperature causes the change of the physiology of plant host, which can be reflected in the increase of the sensitivity or the resistance to the plant pathogens. The resistance to the pathogens becomes effective due to the increased defence of plants, which are the results of the changes in physiology, nutrition status and water ability.

The most important abiotic cause is the climate change that has been highly expressed in the last ten years. Conditions for plant growth and development are completely different between individual years, but one thing is common in this entire period is unevenly distributed rainfall. It is especially expressed during the vegetation period, which adversely affects the vitality and the health of the plants. Moisture, as well as temperature, is the most important climatic factor with strong impact on plant pathogens and their interactions (Agrios, 2005). It is particularly 
important that these two factors have a strong influence on the development, reproduction, survival and dispersal of pathogenic fungi. Their relatively short generations, which are characterized by high mobility and reproductive power, are able to react more quickly to climate change than long-lived organisms such as higher plants and mammals (Menéndez, 2007). In addition to the impact of the changes in the development of host plant and pathogen development, climate changes have an impact on the interaction between the pathogen and the host, which increases the risk of infections, but the resistance power can also be increased. (Coakley et al., 1999; Garrett et al., 2006).

However, strong decline of different forest stands was recorded on the entire area of Serbia, and all the tree species were affected with the decline. Particularly, decline of different coniferous plantations was recorded after the year 2011, and the most affected were artificially established stands of Scots pine (Pinus sylvestris L.), Austrian pine (Pinus nigra Arnold), spruce (Picea abies (L.) Karst.), Douglas fir (Pseudotsuga menziesii (Mirb.) Franco), and Silver fir (Abies alba Mill.). Decline of the other coniferous plantations was also recorded, but the established and affected areas are not so significant, comparing to previously listed hosts.

Intensive field studies on the diagnostic of the main causes of the decline of different coniferous plantations in Serbia were performed between the years 2011 and 2015. In most of the cases, root and but rots of the trees were recorded and different pathogenic fungi were registered and isolated. However, in the plantations of Scots pine, the most often and most aggressive fungi were Heterobasidion annosum (Fr.) Bref. and Armillaria spp., causing root and stem rot of the trees, and Naemacyclus minor on the needles. In the plantations of Austrian pine, Armillaria spp. was recorded on the roots and stem bases of the trees, and Mycosphaerella pini Rostrup apud Munk, Sphaeropsis sapinea (Fr.) Dyko \&Sutton, Lophodermium spp., Naemacyclus niveus (Pers.) Sacc. were the most often parasitic fungi recorded on needles and shoots. In some places, Cenangium ferruginosum Fr. and Gremmeniella abietina (Lagerb.) Morelet, causing the decline of Austrian pine trees, were previously recorded (Karadžić et al. 2011). In the plantations of spruce, the biggest damages and the declines were recorded by Heterobasidion parviporum Niem. \& Korh., as well as by Armillaria spp. Also, different parasitic fungi on needles, including some rusty fungi were recorded on spruce trees in plantations. In the plantations of Douglas fir, the biggest damages were recorded by Armillaria spp., and in some places by needle diseases Phaeocryptopus gaeumannii (Rohde) Petrak and Rhabdocline pseudotsugae Syd.

From the other coniferous species in plantations in Serbia, we could point out European larch (Larix decidua Mill.), that was affected by larch canker disease (Lachnellula willkommii (Hartig) Dennis), as well as white pine (Pinus strobus L.), that was also affected with the decline in some places. In the plantations of silver fir, Heterobasidion abietinum Niem. \& Korh. And Armillaria ostoyae (Romagn.) Herink were the most destructive pathogens, following the development of mistletoe (Viscum album subsp. abietis (Wiesb.) Abromeit.), particularly in older artificially established stands.

Fungal pathogens attacking secondarily thickened roots of trees are amongst the most destructive agents known in forestry. The genera with serious 
impacts in this category in Souteast European forestry are Heterobasidion and Armillaria (Woodward et al., 1998; Kile \& Shaw, 1991; Fox, 2000; Karadžić \& Milijašević 2008). Three species of Heterobasidion are present in Europe, and cause serious damage: $H$. annosum, $H$ parviporum and $H$. abietinum, of which $H$. annosum is arguably the most aggressive species (Woodward et al., 1998; Asiegbu et al., 2005). Amongst the seven species of Armillaria known in Europe, only two, A. mellea and A. ostoyae are serious pathogens. The most affected are stands of European silver fir, Norway spruce, Scotch and Austrian pine in both natural and semi-natural stands. It was shown in several national and international studies that stability of different conifer stands and ecosystems are strongly disturbed without control of fungi from Heterobasidion genus (Woodward et al. 1998). Apart of ecological loss, there are significant economic losses, since the most valuable part of the trees are completely deteriorated by the fungus activity. Also, Armillaria species were recorded as dangerous pathogens to different conifer stands in SE Europe (Keča et al., 2004). Due to evident climatic extremes, recorded over the last decades, infections with Armillaria species are driven with these changes and weak trees without resistance mechanisms are easily colonized with this opportunistic fungus. In many cases, damages by both Heterobasidion and Armillaria were recorded in the same stands, and even on the same trees.

On the basis of long term research on causes of the acute dieback of Picea, Abies, Pinus and Pseudotsuga, in some areas of Southeastern Europe, the conclusion was made that the climate change initiated the increased activity of fungi Armillaria spp. and $H$. annosum which led to the decay of individual trees and spreading in groups of trees. In pine and spruce monocultures afforested within the broadleaved habitats, massive dieback of trees was also a consequence of these two fungi.

The main factors affecting insects distribution are the temperature and habitat requirements specific to each insect herbivore species. Climate can influence ihe geografical distribution of insect species. Moreover, depending on the local climate the same species can present one or more generations per year. The bark beetle, Ips sexdentatus, has one to five generations per year depending on the climatic codition (EPPO, 1997).

Spatial and temporal scales of insect outbreaks increase due to dry summers and mild winters at high elevations. In the last decade, in the Southeastern Europe, intense outbreaks of bark beetles (Coleoptera: Curculionidae, Scolytinae) on spruce and silver fir were recorded.

Ips typographus is mostly a secondary biotic agents, affecting trees that are already weakened. As a result, it is possible to assess the level of risk of forest infestation for this species, according to the combination of environmental traits that are present, and on the management aims. However, I. typographus is currently expanding its range, and interestingly, outbreak risks are similarly high outside its natural range than in non-managed, old-growth spruce stands. Spruce forests on the territory of Central Serbia have been heavily attacked by $I$. typographus and Pityogenes chalcographus, and Austrian and Scots pine forests have been mostly affected by forest fires followed by outbreaks of Ips sexdentatus and other bark beetles. 
Intensive degradation of coniferous tree species has been present for many years in Serbia. Nearly all conifer species are endangered in plantations, in urban areas and in nurseries. The drying causes are very complex and involve a large number of biotic and abiotic factors.

Many plantations are built on an inadequate site. In afforestation and reclamation of degraded forests not enough attention was paid to the ecology of the species which were entered. That's how mesophilic conifers were massively entered in drier broadleaf forests, while they were in middle-aged stage of their development, when they have higher demands for water, where they were stuck by a physiological drought. This has caused the decline of many trees in the cultures of Douglas fir and pine bred on such sites (Lazarev \& Golubović Ćurguz, 2000, 2004). If bred at such, inappropriate sites, due to the specific structure and composition of the soil, where the runoff of excess water is prevented and retained in the rhysosphere, allowing the development of a number of anaerobic pathogens. Excess moisture in plantations of Weymouth pine and larch causes physiological weakening of the trees and they become susceptible to massive development of pathogenic fungi and pests.

As a result of lack of care and improper management of the plantations of the conifer species in Serbia damages were caused by many causes of biotic origin that were developed in different intensity. In older untended silver fir plantations a massive development of mistletoe was recorded, which also causes damaging and decay of trees. By removing these fir trees the circuit is opened and favorable conditions for further development of the mistletoe are made, which causes continued deterioration of fir trees.

Pathogenic fungi Armillaria spp. and $H$. annosum are a frequent cause of deterioration of conifer plantations raised on the habitats of broadleaves species, especially oaks. The consequence of the development of the fungus is that it leads to a massive degradation of coniferous trees. If contemporaneous plantations are raised in these large areas, it enables easy transfer of fungal diseases.

\section{CONCLUSION}

Forest decline, insect outbreaks, forest fires and other negative impacts are driven and intensified by climatic changes. All these phenomena are more frequent in the recent years, threatening different natural and semi-natural ecosystems, including coniferous plantations. Also, these phenomena have catastrophic character in some cases, and they are followed by process of chaining of damages.

Apart of all the negative biotic and abiotic causes, many plantations were established on inadequate sites in the past, what makes them more vulnerable for different stress and declining factors. Particularly, this situation is pointed out in the cases of mesophilic conifers that were introduced in drier broadleaf forests. During the first years of development, they did not have high demands for water supply and remained healthy. Later, during the middle-aged stages of their development, they have higher demands for water, and they suffered from the physiological drought, what caused the decline of many trees, or made them more vulnerable for the infections of opportunistic pathogens and pests attacks. In opposite, introduced species that are not tolerated on excess moisture and water in 
the soil, are also under physiological weakening of the trees in plantations, and they became susceptible on the attacks of pests and opportunistic pathogens.

\section{ACKNOWLEDGEMENTS}

Investigations were carried out within the framework of activities of public interest in the field of harmful organism diagnostics and protection of the health of forest plants on the territory of the Republic of Serbia, excluding the territory of the Autonomous Province of Vojvodina over the period 2015-2019, funded by the Republic of Serbia through the Forest Directorate of the Ministry of Agriculture and Environmental Protection.

\section{REFERENCES}

Agrios, G.N. (2005): Plant Pathology, 5th ed. San Diego, CA, USA: Elsevier-Academic Press.

Asiegbu, F.O., Adomas, A. \& Stenlid, J. (2005): Conifer root and butt rot caused by Heterobasidion annosum (Fr.) Bref. s.l, Molecular Plant Pathology, 6: 395-409.

Coakley, S.M., Scherm, H. \& Chakraborty, S. (1999): Climate change and plant disease management. Annu. Rev. Phytopathol., 37: 399-426.

Bradley, R.S., Diaz, H.F., Eischeid, J.K., Jones, P.D., Kelley, P.M. \& Goodess, C.M. (1987): Precipitation fluctuations over Northern Hemisphere land areas since mid 19th century. Science, 237: 171-175.

Das, H.P. (2004): Adaptation strategies required to reduce vulnerability in agriculture and forestry to climate change, climate variability and climate extremes. In World Meteorological Organization (WMO). Management Strategies in Agriculture and Forestry for Mitigation of Greenhouse Gas Emissions and Adaptation to Climate Variability and Climate Change, Report of CAgM Working Group. Technical Note No. 202, WMO No. 969, Geneva, WMO, pp. 41-92.

EPPO (1997): Pest risk assessment scheme - EPPO Bull, 27: 281-305

Fox, R.T.V. (2000): Armillaria Root Rot: Biology and Control of Honey Fungus. Intercept Press, Andover, UK.

Garrett, K.A., Dendy, S.P., Frank, E.E., Rouse, M.N. \& Travers, S.E. (2006): Climate change effects on plant disease: genomes to ecosystems. Annual Review of Phytopathology, 44: 489-509.

Karadžić D. \& Milijašević T. (2008): The most important parasitic and saprophytic fungi in Austrian pine and scots pine plantations in Serbia. Bulletin of the Faculty of Forestry, 97: 147-170.

Keča, N., Bodles, W.A.J., Woodward, S. \& Karadžić, D. (2004): Identification of Armillaria spp. in Serbia, Proccedings of the $11^{\text {th }}$. International Conference on "Root and Butt Rots of Forest Trees”. Poznań and Bialowezy, Poland, august 16-22, 35-41.

Kile, G.A. \& Shaw C.G. (1991): Armillaria Root Disease. USDA Forest Service, Agriculture Handbook No. 691. 
Lazarev, V. \& Golubović-Ćurguz, V. (2000): Rabdocline pseudotsugae Syd. - nova bolest četina duglazije u Srbiji, Šumarstvo (Beograd), 2-3: 79-86.

Lazarev, V. \& Golubović-Ćurguz, V. (2004): Nalaz Rhizosphaera kalkoffii Bubak izazivača osipanja četina na Picea omorika (Pančić) Purkyne, Šumarstvo (Beograd), 1-2: 81-87.

Liovic, B. \& Zupanic, M. (2005). Forest Pests in National Parks of Croatia and Ecologically Acceptable Protective Measures. Forests institute Works (Jastrebarsko), 40(1): 101-112,.

Menéndez, R. (2007). How are insects responding to global warming? Tijdschrift voor Entomologie, 150: 355-365.

Mortsch, L.D. (2006): Impact of climate change on agriculture, forestry and wetlands. In Bhatti, J., Lal, R., Apps, M. \& Price, M., eds. Climate change and managed ecosystems, pp. 45-67. Taylor and Francis, CRC Press, Boca Raton, FL, US.

Rosenzweig, C., Iglesias, A., Yang, X.B., Epstein, PR. \& Chivian, E. (2001): Climate change and extreme weather events, Implications for food production, plant diseases, and pests, Global change \& human health, 2(2): 90-104.

Tabaković-Tošić, M. (2014): The condition of tree crowns at the sample plots of level Ireliable or unreliable indicators of the vitality of main conifer species in Serbian forests. 3rd ICP Forests Scientific Conference "Impact of nitrogen deposition and ozone on the climate change mitigation potential and sustainability of European forests". Athens, Greece, May 26-28, 27.

Tabaković-Tošić, M. \& Milosavljević, M. (2015): Impact of extreme weather conditions on the population dynamics of bark beetles in the forests of eastern Serbia. Suistainable Forestry, 71-72: 27-37.

Willmott, C. J. \& Legates, D. R. (1991): Rising estimates of terrestrial and global precipitation. Climate Research, 1: 179-186.

Woodward S., Stenlid J., Karjalainen R. \& Hüttermann A. (1998): Heterobasidion annosum: Biology, ecology, impact and control. Wallingford, UK: Cab International. 